Zeszyty Naukowe Szkoły Głównej Gospodarstwa Wiejskiego w Warszawie Problemy Rolnictwa Światowego tom 17 (XXXII), zeszyt 3, 2017: 145-153

DOI: 10.22630/PRS.2017.17.3.61

Michał Jasiński ${ }^{1}$, Anna Masłoń-Oracz ${ }^{2}$

Szkoła Główna Handlowa w Warszawie

\title{
Rolnictwo i turystyka w rozwoju społeczno-ekonomicznym Mauritiusu
}

\section{Agriculture and Tourism in Socio-economic Development in Mauritius}

\begin{abstract}
Synopsis. Celem tego opracowania jest przedstawienie, analiza i ocena miejsca rolnictwa i turystyki w procesie rozwoju społeczno-ekonomicznego Mauritiusu. Jest to państwo, któremu pomimo, silnie ograniczających uwarunkowań geograficznych, udało się przyspieszenie (w ostatnich 20-30 latach) procesu rozwoju społeczno-ekonomicznego. To stało sie podstawą i wstępem do zainicjowania badań tej afrykańskiej - wyspiarskiej gospodarki.
\end{abstract}

Słowa kluczowe: rolnictwo, turystyka, rozwój społeczno-ekonomiczny, małe gospodarki wyspiarskie, monokultura turystyczna

\begin{abstract}
Africa is viewed as the next business frontier worldwide. In the last decade, we have been witnessing increased investment operations in Africa by US, Chinese, Japanese and European companies. The restrictions of African agricultural production and tourism as a prosperous industry are possible to overcome. The future prospects are favorable. The economy of Mauritius is based on sugar, tourism, textiles and apparel, and financial services, and is rapidly expanding into fish processing, ICT, hospitality and property development. The aim of this paper examines the environment for developing agro and tourism business in Mauritius, which in turn strengthens the private sector. It also identifies opportunities that can stimulate the countries' broader reform efforts with the ultimate goal of poverty reduction.
\end{abstract}

Key words: agriculture, tourism, socio-economic development, small island economies, tourism monoculture

\section{Wprowadzenie}

„Wszyscy należymy do Afryki ... To kolebka ludzkości, tu nauczyliśmy się chodzić, mówić, bawić się i kochać. Nić łącząca nas z afrykańskimi przodkami rozciąga się przez tysiące pokoleń, ale wciąż porusza czułe struny w naszych sercach, kiedy zachwycamy się afrykańskimi krajobrazami, dziką przyrodą i ludźmi - John Reader" (Godwin, 2001, s. 10).

Afryka staje się obszarem wielkich możliwości inwestycyjnych i oferuje potencjał gospodarczy, który systematycznie staje się większą alternatywą dla rynków Azji. Osiągane tam stopy zwrotu z prowadzonych przedsięwzięć biznesowych należą do najwyższych na świecie. Tak korzystna sytuacja inwestycyjna utrzymuje się od 1990 r. Od 2002 r. dynamika wzrostu gospodarczego na kontynencie afrykańskim doprowadziła do potrojenia wartości

\footnotetext{
${ }^{1}$ dr, Katedra Unii Europejskiej im. Jeana Monneta, SGH w Warszawie, ul. Wiśniowa 41, 02-520 Warszawa, e mail: michal.jasinski@sgh.waw.pl

${ }^{2}$ dr, Katedra Unii Europejskiej im. Jeana Monneta, SGH w Warszawie, ul. Wiśniowa 41, 02-520 Warszawa e-mail: amaslon@sgh.waw.pl
} 
tamtejszej gospodarki. Tę tendencję i wynikającą z niej szansę zauważyły największe potęgi gospodarcze jak Stany Zjednoczone Ameryki, Chiny (szczególnie aktywne w tym regionie), Japonia i Rosja. Swoją politykę gospodarczą pod kątem potencjału rynku afrykańskiego odpowiednio modyfikują także byłe mocarstwa kolonialne takie, jak Francja czy Wielka Brytania. Aktywna w regionie jest też Turcja i Korea Południowa. Według Banku Światowego (2017) wzrost gospodarczy krajów Afryki Subsaharyjskiej powinien w najbliższych latach przekroczyć istotnie światową średnią. Co czwarty afrykański kraj osiąga od 2013 r. przynajmniej 5-6\% wzrost gospodarczy. Szczególnie korzystne dla Afryki są dane dotyczące perspektyw wzrostu konsumpcji oraz liczby i wartości inwestycji. Sektory rolnictwa i turystyki stanowią $\mathrm{w}$ wielu państwach afrykańskich dźwignię rozwoju społecznoekonomicznego.

Mauritius jest specyficzną - afrykańską małą gospodarką wyspiarską (powierzchnia 2 tys. $\mathrm{km}^{2}$ ) zlokalizowaną na Oceanie Indyjskim. Uwarunkowania geograficzne (małe rozmiary, ograniczone zasoby naturalne, izolacja, klęski żywiołowe) determinują wąską specjalizację i marginalne znaczenie w handlu międzynarodowym tego państwa. Podobnie, jak i innych małych państw wyspiarskich (Small Island Developing States - SIDS ${ }^{3}$ ), gospodarka Mauritiusu nie jest w stanie wykorzystać efektu skali, uzależnieniona jest od importu, charakteryzują ją niski stopnień wykorzystania zasobów pracy, kulturowa dominacja Północy, wysokie koszty transportu, infrastruktury i administracji oraz podatność na działalność przestępczą (pranie brudnych pieniędzy, narkotyki, korupcja). Pomimo pozornie wspólnych cech z innymi SIDS nie występuje tam, ani zjawisko „monokultury turystycznej”, ani „monokultury pomocowej” - specyficznych, ekstremalnych form choroby holenderskiej ${ }^{4}$ - tak charakterystycznych dla tej grupy. Od innych małych państw wyspiarskich odróżnia je również wysoki (w kategoriach SIDS, jak i państw afrykańskich) poziom rozwoju społeczno-ekonomicznego (Jasiński, 2017).

Przełamanie silnie ograniczających uwarunkowań środowiska przyrodniczego (brak żyznych gleb, słodkiej wody, ograniczona fauna i flora) - wejście na ścieżkę dynamicznego rozwoju - specyficzny (wyspiarski, ale również i afrykański) sukces społeczno-gospodarczy stał się pretekstem poszukiwania jego źródeł, w tym szczególnie do próby odpowiedzi na pytanie - na ile sektory rolnictwa i usług turystycznych przyczyniły się, szczególnie w XXI w., do podniesienia poziomu - nie tylko wzrostu, ale szeroko rozumianego rozwoju społeczno-ekonomicznego Mauritiusu. Za cel artykułu autorzy postawili sobie analizę i ocenę miejsca rolnictwa i turystyki w procesie rozwoju społeczno-ekonomicznego tego państwa. Jego osiągnięcie stanowi wprowadzenie do dalszych badań przyczyn sukcesu rozwojowego tego afrykańskiego państwa.

\footnotetext{
${ }^{3}$ Zgodnie z klasyfikacją (UNCTAD, 2010, s. 5) za SIDS przyjmuje się 29 niezależnych państw: 13 na Oceanii (Federacyjne Stany Mikronezji, Fidżi, Kiribati, Nauru, Palau, Papua Nowa Gwinea, Samoa, Timor Wschodni, Tuvalu, Vanuatu, Wyspy Marshalla, Wyspy Salomona oraz Wyspy Tonga); 10 karaibskich (Antigua i Barbuda, Bahamy, Barbados, Dominika, Grenada, Jamajka, Saint Kitts i Nevis, Saint Lucia, Saint Vincent i Grenadyny oraz Trynidad i Tobago); 2 położone na Atlantyku Wschodnim (Republika Zielonego Przylądka oraz Wyspy Świętego Tomasza i Książęca) oraz 4 na Oceanie Indyjskim (Malediwy, Mauritius, Seszele oraz Związek Komorów).

${ }^{4}$ Rozwój gospodarki turystycznej, jaki i pomoc rozwojowa mogą w szczególnych przypadkach przyczynić się do wystąpienia choroby holenderskiej (Dutch disease) - zjawiska powodującego m.in. regres niektórych działów gospodarki oraz spadek dywersyfikacji wywozu i nadmierne uzależnienie eksportu i gospodarki państwa od wpływów ze sprzedaży jednego czy kilku surowców (monokultura).
} 


\section{Rolnictwo na Mauritiusie}

Rolnictwo na Mauritiusie było jedną z dominujących gałęzi gospodarki, która ma duży udział w zatrudnieniu. Zdecydowanie cechuje się obecnie dość dobrym stopniem mechanizacji oraz kultury rolnej. Ze względu na bardzo korzystny agroklimat, większość upraw koncertuje się na roślinach ciepłolubnych (uprawy herbaty, ziemniaków, bananów, kukurydzy, tytoniu oraz przypraw - goździki, muszkatołowiec) (African Development Bank, 2016). Na przestrzeni ostatnich kilkudziesięciu lat sektor rolny przeszedł transformację od sektora opartego na jednowymiarowej uprawie roli w latach $60 . \mathrm{XX}$ w. do w pełni zdywersyfikowanej gospodarki rolno-spożywczej. Obecnie przemysł rolno- spożywczy składa się z pięciu głównych sektorów: 1) trzcina cukrowa, 2) świeże produkty rolne, 3) żywność przetworzona, 4) owoce morza, 5) alkohole i napoje (Por. Informator Ekonomiczny MSZ, 2017). W rzeczywistości agrobiznes jest jednym z głównych obszarów gospodarczych na Mauritiusie (4,5\%), obok sektora usług (73,4\%), a także przemysłu $(22,1 \%)$ (FAO Statistical Pocketbook, 2015).

Rolnictwo stanowi nie tylko znaczną część gospodarki tego państwa, ale jest również bardzo dynamiczny. Rolnictwo na Mauritiusie jest wspierane przez rząd poprzez narodową strategię, celem zwiększenia wydajności i jakości dzięki programowi dystrybucji nawozów i szkolenia rolników.

Sektor rolnictwa na Mauritiusie nie spełnia dwóch podstawowych funkcji: produkcyjnej i wyżywieniowej. Importowane są zarówno ilości świeżych warzyw oraz owoców (jabłka, cytrusy, winogrona), głównie na potrzeby zlokalizowanej na Mauritiusie branży hotelarskiej, jak i w coraz większym stopniu Mauritius staje się importerem netto żywności. Zapotrzebowanie na żywność netto szacuje się na 690000 t rocznie, z czego 75\% to import produktów rolnych i produktów spożywczych, które corocznie osiągają rekordowe poziomy co wskazuje na wysoki poziom zależności handlowej. Rosnące podwyżki cen żywności i pasz, wraz z rosnącymi opłatami frachtowymi i wahaniami kursów walut, wywołały wysoki deficyt bilansu płatniczego.

Tabela 1. Wartość eksportu i importu żywności na Mauritiusie w latach 1990, 2000, 2014 (w mln USD)

Table 1. Export and imports of food in Mauritius in 1990, 2000, 2014

\begin{tabular}{c|ccc}
\hline Lata & 1990 & 2000 & 2014 \\
\hline Export żywności (mln USD) & 365 & 233 & 320 \\
Import żywności (mln USD) & 162 & 229 & 698 \\
\hline
\end{tabular}

Źródło: FAO Statistical Pocketbook, 2015.

Podstawę gospodarki stanowią plantacje trzciny cukrowej (ok. 90\% gruntów ornych) i pomimo prób przełamania monokulturowości, uprawy te wciąż dominują (por. Przewodnik Travel Planet, 2017). Produkcja cukru w 2016 roku wzrosła na Mauritiusie w relacji rocznej o 9\% do 400 tys. ton. Wdrażanie nowej strategii dywersyfikacji przemysłu rolnospożywczego, z pewnością w krótkiej perspektywie nie spowoduje znaczącej zmiany w pozycji tej wyspy jako kluczowego dostawcy cukru do UE wśród krajów Afryki, Karaibów i Pacyfiku. Duże znaczenie ma hodowla bydła, owiec, kóz i drobiu oraz rybołówstwo. Rząd koncentruje się na rozbudowie przemysłu włókienniczego i spożywczego (cukrownie, przetwórnie ryb, wytwórnie napojów, w tym alkoholowych i inne) (FAO Statistical Pocketbook, 2015). 
Ze względu na zmianę nawyków konsumentów w kierunku przetworzonych produktów rolnych, oraz zwracania uwagi na jakość, bezpieczeństwo żywności i markę, rząd maurytyjski podjął szereg działań aby sprostać wyzwaniu. Badanie wydatków w gospodarstwach domowych (2012-2013) wykazało, że przeciętnie gospodarstwo domowe przeznacza około $31 \%$ całkowitych wydatków na żywność.

W analizowanym okresie (1990-2014) wartość eksportu żywności spadła z 365 mln USD w 1990 r do 320 mln USD w 2014 r. (tab. 1). Główną przyczyną jest drastyczny wzrost importu przetworzonych produktów żywnościowych (w tym przetwórstwo warzywne) w okresie 1990-2014, z odpowiednio $162 \mathrm{mln}$ USD do $698 \mathrm{mln}$ USD. Oczekuje się, że ta tendencja się utrzyma.

\section{Eksport produktu turystycznego a poziom rozwoju społecznego i zamożności Mauritiusu}

Początki proeksportowej specjalizacji turystycznej Mauritiusu sięgają pierwszej połowy lat 70. XX w. Strategia ta wymagała rozwoju przede wszystkim infrastruktury turystycznej W celu stworzenia konkurencyjnego na światowym rynku produktu turystycznego. Decydujące znaczenie miała wielkość zewnętrznego popytu turystycznego. Podstawowa zaletą strategii turystycznej była możliwość „eksportu” zasobów przyrody, których nie można „sprzedać” w inny sposób $(3 \mathrm{xS}-$ sun, sea, sand) oraz pozyskiwanie z tego tytułu wpływów dewizowych. W literaturze przedmiotu podkreśla się, że realizacja tej strategii w przypadku państw rozwijających się wiązała się z szeregiem negatywnych zjawisk zarówno na płaszczyźnie ekonomicznej, społeczno-kulturowej, jak i ekologicznej (szerzej patrz: Alejziak, 2000; Kurek, 2007). W przypadku małych rozwijających się państw wyspiarskich za podstawowe (z gospodarczej perspektywy) zagrożenie uznaje się zjawisko „monokultury turystycznej” (Giezgała, 1969, 1977; Jasiński, 2006, 2008; Kachniewska, Niezgoda, Pawlicz, 2012; Wodejko, 1998).

W przypadku Mauritiusu nie można jednak mówić o wystąpieniu tego zjawiska, pomimo występowania pewnych przesłanek (m.in. wysoki wskaźnik wpływów z turystyki w $\mathrm{PKB}^{5}$ - tabela 2). O ile w początkowej fazie rozwoju specjalizacji turystycznej nastąpił dynamiczny rozwój gospodarki turystycznej, to w pewnym momencie został on wyhamowany. „Wyhamowanie” to było świadomym zabiegiem rządu Mauritiusu, który świadomy możliwości wystąpienia zjawiska „monokultury turystycznej” - ograniczał dalszy ilościowy rozwój bazy noclegowej. Dążąc przy tym do utrzymania stabilnego przyjazdowego ruchu turystycznego. W szerszym kontekście miało to na celu przeciwdziałanie zjawisku (wynikającego z twierdzenia Rybczyńskiego) „wypierania” przez turystykę innych działów gospodarki.

Współcześnie proeksportowa specjalizacja turystyczna Mauritiusu jest wyraźna stanowi specyficzną funkcję motoryczną w procesie rozwoju społeczno-ekonomicznego. Dane z tabeli 2 wskazują na znaczące (jednak nie dominujące) oddziaływanie wpływów z eksportu produktu turystycznego na rozwój tego państwa.

\footnotetext{
${ }^{5}$ Za umowną wartość, kiedy gospodarka zaczyna ulegać „degradacji” i staje się „,zależna” od eksportu produktu turystycznego w literaturze przedmiotu przyjęto w latach 80 . XX w. przekroczenie $20 \%$ wskaźnika, w latach 90 . XX w. 25\% (Wodejko, 1989, 1998).
} 
W analizowanym okresie (lata 2001-2015) wyraźne są tendencje wzrostowe wskaźników rozwoju społecznego (HDI) i zamożności (PKB). Pierwszy, w przeciągu 15-letniego okresu wzrósł z 0,683 w 2001 roku do 0,781 w 2015 r. (tab. 2). Plasowało to Mauritius (w 2015 r.) na 5 miejscu, spośród SIDS o najwyższym poziomie rozwoju społecznego na świecie - po karaibskich: Barbadosie, Bahamach, Antigui i Barbudzie oraz znajdujących się na Oceanie Indyjskim Seszelach (Human Development Report, 2016). Również wyraźny jest progres drugiego wskaźnika (zamożności). PKB (pomimo niewielkich spadków w roku 2005, 2009 i 2015) wzrósł z 4,7 mld USD w 2001 r. do blisko 11,7 mld USD w 2015 r. (tab. 2). W przeliczeniu PKB na 1 mieszkańca tendencja wzrostowa jest równie wyraźna - z 3 792,2 USD w 2001 r. do 10 153,9 USD w 2014 r. (tab. 2).

Wzrost wskaźników HDI i PKB jest skorelowany z wpływami z turystyki, co jest szczególnie wyraźne w latach 2001-2008. Eksport produktu turystycznego, który wykazuje tendencję wzrostową w tym okresie (z 820 mln USD w 2001 r. do 1,823 mld USD w 2008 r.) wpływa na PKB, które $\mathrm{w}$ tym okresie również wzrasta (poza niewielkim spadkiem w 2005 r.). Zmniejszenie liczby turystów na Mauritiusie w 2009 r. w stosunku do 2008 r. (tab. 3) wywołany ogólnoświatowym kryzysem (turystykę uznaje się za najczulszy barometr sytuacji kryzysowych na świecie) wpłynął na spadek wielkości eksportu produktu turystycznego tego państwa. To z kolei wpływa na spadek PKB (tab. 2).

Tabela 2. Wybrane wskaźniki rozwoju społeczno-ekonomicznego i turystyki na Mauritiusie w latach 2001-2015

Table 2. Selected socio-economic and tourism indicators in Mauritius in 2001-2015

\begin{tabular}{c|cccccc}
\hline Lata & HDI & $\begin{array}{c}\text { PKB } \\
\text { (mld USD) }\end{array}$ & $\begin{array}{c}\text { Wpływy } \\
\text { z turystyki } \\
\text { (w mld USD) }\end{array}$ & $\begin{array}{c}\text { Wpływy } \\
\text { z turystyki } \\
\text { w PKB (w\%) }\end{array}$ & $\begin{array}{c}\text { PKB } \\
\text { per capita } \\
\text { (w USD) }\end{array}$ & $\begin{array}{c}\text { Wpływy } \\
\text { turystyki } \\
\text { per capita } \\
\text { (w USD) }\end{array}$ \\
\hline 2001 & 0,683 & 4,537 & 0,820 & 18,1 & 3792,2 & 685,5 \\
2002 & 0,687 & 4,767 & 0,829 & 17,4 & 3957,5 & 688,2 \\
2003 & 0,696 & 5,610 & 0,960 & 17,1 & 4623,3 & 791,2 \\
2004 & 0,704 & 6,386 & 1,156 & 18,1 & 5229,9 & 946,8 \\
2005 & 0,713 & 6,284 & 1,189 & 18,9 & 5116,0 & 968,0 \\
2006 & 0,720 & 7,029 & 1,302 & 18,5 & 5696,0 & 1055,1 \\
2007 & 0,728 & 8,150 & 1,663 & 20,4 & 6574,7 & 1341,5 \\
2008 & 0,734 & 9,990 & 1,823 & 18,2 & 8030,1 & 1465,3 \\
2009 & 0,740 & 9,129 & 1,390 & 15,2 & 7318,1 & 1114,3 \\
2010 & 0,748 & 10,004 & 1,585 & 15,8 & 8000,4 & 1267,6 \\
2011 & 0,756 & 11,518 & 1,808 & 15,7 & 9197,0 & 1443,6 \\
2012 & 0,765 & 11,669 & 1,778 & 15,2 & 9291,2 & 1415,7 \\
2013 & 0,769 & 12,130 & 1,593 & 13,1 & 9637,0 & 1265,6 \\
2014 & 0,779 & 12,803 & 1,719 & 13,4 & 10153,9 & 1363,3 \\
2015 & 0,781 & 11,682 & 1,679 & 14,4 & 9252,1 & 1329,8 \\
\hline
\end{tabular}

Źródło: Bank Światowy, 2017; Human Development Report, 2016, obliczenia własne.

Uzyskane w następnych latach wielkości ruchu przyjazdowego, jak i wpływy z tego tytułu odzwierciedlają reakcję rządu Mauritiusu na zaistniałą sytuację kryzysową. W wyniku spadku liczby przyjazdów w 2009 r. obniżono ceny produktu turystycznego. Spowodowało to zwiększenie ruchu turystycznego w następnym roku - do poziomu „przedkryzysowego” z 2008 r. (tab. 3). W wyniku obniżenia cen produktu turystycznego nie osiągnięto jednak 
w 2010 r. zbliżonego poziomu wpływów z tytułu jego eksportu z 2008 r. Nie spowodowało to jednak spadku PKB w $2010 \mathrm{r}$. - był on nawet wyższy niż w $2008 \mathrm{r}$. W następnych latach niewielkie wahania wpływów $\mathrm{z}$ turystyki również nie wpłynęły na obniżenie PKB (za wyjątkiem 2015 r.), ani wskaźnika HDI. Wskazuje to na rosnące znaczenie innych sektorów gospodarki Mauritiusu. Niewielkie obniżenie znaczenia funkcji turystyki w procesie rozwoju społeczno-ekonomicznego, potwierdza również wskaźnik wpływów z turystyki w PKB. W okresie rosnących wpływów (w latach 2001-2008) wynosił on od $17,1 \%$ do $20,4 \%$. W okresie po 2009 r. wahał się w przedziale $13,1 \%$ - 15,8\% (tab. 2 ).

Tabela 3. Ludność miejscowa a turyści zagraniczni na Mauritiusie w latach 2001-2015

Table 3. Population and tourist in Mauritius in 2001-2015

\begin{tabular}{l|cccccc}
\hline Lata & $\begin{array}{c}\text { Gęstość } \\
\text { zaludnienia } \\
\text { (liczba } \\
\text { mieszkańców } \\
\text { na km²) }\end{array}$ & $\begin{array}{c}\text { Liczba } \\
\text { mieszkańców } \\
\text { (w mln) }\end{array}$ & $\begin{array}{c}\text { w tym: } \\
\text { zamieszkująca } \\
\text { obszary } \\
\text { miejskie } \\
\text { (w mln) }\end{array}$ & $\begin{array}{c}\text { Ludność } \\
\text { miejska } \\
\text { względem } \\
\text { całej populacji } \\
\text { (w \%) }\end{array}$ & $\begin{array}{c}\text { Liczba } \\
\text { turystów } \\
\text { zagranicznych } \\
\text { (w mln) }\end{array}$ & $\begin{array}{c}\text { Liczba } \\
\text { turystów } \\
\text { zagranicznych } \\
\text { do stałych } \\
\text { mieszkańców } \\
\text { (w \%) }\end{array}$ \\
\hline 2001 & 589,3 & 1,196 & 0,508 & 42,5 & 0,660 & 55,2 \\
2002 & 593,4 & 1,205 & 0,509 & 42,2 & 0,682 & 56,6 \\
2003 & 597,7 & 1,213 & 0,510 & 42,0 & 0,702 & 57,9 \\
2004 & 601,5 & 1,221 & 0,511 & 41,8 & 0,719 & 58,9 \\
2005 & 605,1 & 1,228 & 0,511 & 41,6 & 0,761 & 62,0 \\
2006 & 607,9 & 1,234 & 0,511 & 41,4 & 0,788 & 63,9 \\
2007 & 610,7 & 1,240 & 0,511 & 41,2 & 0,907 & 73,2 \\
2008 & 612,9 & 1,244 & 0,510 & 41,0 & 0,930 & 74,8 \\
2009 & 614,5 & 1,247 & 0,509 & 40,8 & 0,871 & 69,8 \\
2010 & 616,0 & 1,250 & 0,507 & 40,6 & 0,935 & 74,8 \\
2011 & 616,9 & 1,252 & 0,506 & 40,4 & 0,965 & 77,1 \\
2012 & 618,7 & 1,256 & 0,504 & 40,2 & 0,965 & 76,8 \\
2013 & 620,0 & 1,259 & 0,503 & 40,0 & 0,993 & 78,9 \\
2014 & 621,1 & 1,261 & 0,502 & 39,8 & 1,039 & 82,4 \\
2015 & 622,0 & 1,263 & 0,501 & 39,7 & 1,151 & 91,2 \\
\hline
\end{tabular}

Źródło: Bank Światowy, 2017, obliczenia własne.

Wnikliwsza analiza wielkości przyjazdowego ruchu turystycznego (który w znacznym stopniu determinuje wielkość wpływów z eksportu produktu turystycznego - szerzej patrz: Wodejko, 1998) w okresie po 2009 r. wskazuje, że prowadzona polityka turystyczna przez rząd Mauritiusu nakierowana jest na utrzymanie stałych (bądź wyższych) wpływów $\mathrm{z}$ turystyki, może generować dodatkowe zagrożenia $\mathrm{w}$ sferach społeczno-kulturowych i ekologicznych. Wzrastająca liczba turystów (w 2014 r. przekroczyła $1 \mathrm{mln}$ ) powoduje, że i tak na gęsto zaludnionym (w porównaniu z innymi SIDS) Mauritiusie (622 osoby na $1 \mathrm{~km}^{2}$ w 2015 r.) może dojść do tzw. przeciążenia przestrzeni turystycznej (Włodarczyk, 2009). Pomimo względnie równomiernego rozłożenia przyjazdów turystów w roku (jak wskazują dane statystyczne nie można mówić o sezonowości w przypadku tego państwa - por. Digest of International Travel and Tourism Statistics, 2011, 2016), to wyraźny jest wzrost odsetka liczby turystów do stałych mieszkańców (w 2015 r. sięgnął on 91,2\%). To tzw. przeciążenie wiąże się nie tylko z kosztami ekologicznymi (odpady, czy konflikt o wodę pitną), ale może powodować również niechęć do bezpośredniego kontaktu ludności miejscowej z turystami. 
Odzwierciedleniem tego może być powolny proces dezurbanizacji demograficznej (tab. 3) na obszarach zurbanizowanych na Mauritiusie skoncentrowany jest głównie ruch turystyczny.

Tabela 4. Wielkość bazy hotelowej na Mauritiusie w latach 2001-2015

Table 4. Hotels and its capacity in Mauritius in 2001-2015

\begin{tabular}{|c|c|c|c|c|}
\hline Lata & Liczba hoteli & $\begin{array}{l}\text { Liczba pokoi } \\
\text { hotelowych }\end{array}$ & $\begin{array}{l}\text { Liczba łóżek } \\
\text { hotelowych }\end{array}$ & $\begin{array}{c}\text { Liczba pokoi } \\
\text { hotelowych } \\
\text { na } \mathrm{km}^{2}\end{array}$ \\
\hline 2001 & 95 & 9024 & 18350 & 4,4 \\
\hline 2002 & 95 & 9623 & 19597 & 4,7 \\
\hline 2003 & 97 & 9647 & 19727 & 4,8 \\
\hline 2004 & 103 & 10640 & 21355 & 5,2 \\
\hline 2005 & 99 & 10497 & 21072 & 5,2 \\
\hline 2006 & 98 & 10666 & 21403 & 5,3 \\
\hline 2007 & 97 & 10857 & 21788 & 5,3 \\
\hline 2008 & 102 & 11488 & 23095 & 5,7 \\
\hline 2009 & 102 & 11456 & 23235 & 5,6 \\
\hline 2010 & 112 & 12075 & 24698 & 5,9 \\
\hline 2011 & 109 & 11925 & 24242 & 5,9 \\
\hline 2012 & 117 & 12527 & 25496 & 6,2 \\
\hline 2013 & 107 & 12376 & 25105 & 6,1 \\
\hline 2014 & 105 & 12799 & 26174 & 6,3 \\
\hline 2015 & 107 & 13617 & 28732 & 6,7 \\
\hline
\end{tabular}

Źródło: Digest of International Travel and Tourism Statistics, 2011, 2016.

Przestrzeń turystyczna wiąże się nie tylko z turystami (konsumentami tej przestrzeni) i stałymi mieszkańcami, ale również z rozbudową infrastruktury turystycznej (Włodarczyk, 2009). W dużym uproszczeniu, ograniczając się tylko do bazy hotelowej na Mauritiusie stwierdzić należy, że widoczny jest proces rozbudowy tej bazy, szczególnie po $2010 \mathrm{r}$. (tab. 4). Budowane są nie tylko nowe obiekty hotelowe, ale powiększana jest również istniejąca baza (wzrost liczby pokoi, jak i łóżek). Zabiegi te potwierdzają politykę turystykę rządu opierającą się na dążeniu do utrzymania (zwiększania) wpływów z turystyki poprzez zwiększanie liczby turystów. W przypadku obniżenia cen produktu turystycznego (w 2010 r.) wydaje się to być jedyna rozsądna droga w krótkim okresie czasu.

\section{„Monokultura turystyczna” a rozwój}

W szerszym kontekście należy zastanowić się, jak należy ocenić znaczną część SIDS, które eksportują głównie usługi turystyczne i które dotknęło zjawisko „,monokultury turystycznej"? Gospodarki tych państw nastawione są na obsługę znacznych strumieni turystów (głównie) amerykańskich i europejskich - ale niewiele produkują, importując niemal wszystko, co niezbędne do zaspokojenia nie tylko potrzeb turystów, ale również stałych mieszkańców - włącznie z większością artykułów żywnościowych. Odpowiedź wydaje się być raczej krytyczna. Argumentem jest przede wszystkim bezpieczeństwo ekonomiczne. SIDS z jednostronnie rozwiniętą gospodarką turystyczną narażone są na różne 
szoki i wstrząsy z zewnątrz o wiele silniejsze, niż gdyby ich gospodarka była bardziej zdywersyfikowana (Wodejko, 1998). Co by się stało w przypadku masowego odpływu ruchu turystycznego? Bez względu, czy przyczyny były by natury ekonomicznej, politycznej, zdrowotnej, czy związane z zagrożeniem terrorystycznym - oznaczałoby to katastrofę ekonomiczną dla tych SIDS (por. Garbicz, 2012).

Wiele wysoko rozwiniętych państw tradycyjnie utrzymywało (i nadal to robi) nieefektywne gałęzie rolnictwa (i/lub przemysłu) jedynie w celu, aby być odpornym na polityczny szantaż, presję ekonomiczną, groźby blokad i embargo dostaw. W przypadku np. państw Unii Europejskiej nie muszą one pojedynczo dążyć do tak rozumianego bezpieczeństwa ze względu na tworzenie wspólnego obszaru gospodarczego. Unia jako całość na pewno nie zrezygnuje z rozwijania strategicznych sektorów gospodarki, takich jak rolnictwo (w zakresie decydującym o bezpieczeństwie żywnościowym), czy kluczowych gałęzi przemysłu (m.in. energetyki), tylko dlatego, że tak sugeruje (wąsko pojmowany) rachunek ekonomiczny. W przypadku długiego okresu jest to ryzykowne - zgodnie z opinią Garbicza (2012, s. 69) - „obowiązuje filozofia stania na wielu nogach” (dywersyfikacja).

Wypierane przez działalność turystyczną innych sektorów gospodarki, szczególnie (tradycyjnego w przeszłości dla SIDS) rolnictwa, tak wyraźnego w małych państwach wyspiarskich (Jędrusik, 2005) wydaje się być raczej błędne. Jakkolwiek, można znaleźć przykłady SIDS na świecie, które odniosły (choć dyskusyjny) sukces w oparciu o eksport produktu turystycznego (m.in. Bahamy, Barbados, czy Seszele). Sukces w tej grupie wynikał ze specyficznego - mądrego (kontrolowanego) zarządzania sektorem turystycznym. W przypadku Bahamów - stanowił on konieczną fazę do rozwoju bardziej wyrafinowanych usług (finansowo-bankowych) - podobnie, jak w przypadku Barbadosu i Seszeli (jak również analizowanego Mauritiusu). Z tym, że w dwóch ostatnich państwach (Barbados, Seszele) charakterystyczne było ,podpieranie” się rolnictwem. „Monokultura turystyczna” nigdy w tych dwóch państwach nie była silna (Jasiński, 2017).

W przypadku Mauritiusu za podstawę sukcesu społeczno-ekonomicznego należy przyjąć, nie tylko podtrzymywanie rolnictwa, jako specyficznego „zabezpieczenia” ekonomicznego, ale również jako element wkomponowany (chociaż w niewielkim stopniu) w gospodarkę turystyczną.

\section{Podsumowanie}

Wstępna analiza zjawiska rolnictwa i turystyki na Mauritiusie umożliwiła na tym etapie stwierdzenie, że zarówno jeden, jak i szczególnie drugi z sektorów przyczynił się $\mathrm{W}$ znacznym stopniu do przyspieszenia procesu rozwoju społeczno-ekonomicznego w tym państwie. W konsekwencji do osiągnięcia znacznego progresu rozwoju społecznego i zamożności, plasującego Mauritius w gronie najwyżej rozwiniętych gospodarek afrykańskich, jak i do grona pięciu najwyżej rozwiniętych SIDS.

$\mathrm{Za}$ podstawowe źródło tego sukcesu należy uznać mądrą (kontrolowaną) i konsekwentną politykę rządu. Za szczególnie istotne w tej kwestii należy uznać niedoprowadzenie do zjawiska „monokultury”. Zarówno na poziomie rolnictwa - ucieczka (w miarę możliwości i ograniczających ją czynników) od „monokultury cukrowej”, jak i kontrolowanie rozwoju sektora turystycznego. Istotne jest również unikanie „,monokultury usługowej” - tzn. wyraźny jest rozwój innych usług (np. finansowo-bankowych). 
Dywersyfikacja gospodarcza wydaje się być w przypadku Mauritiusu wstępną odpowiedzią na podstawowe pytanie o główną przyczynę sukcesu. To oczywiście wymaga dalszych pogłębionych badań. Parafrazując jednak przytoczoną wcześniej myśl (Garbicz, 2012) - w przypadku Mauritiusu niewątpliwie obowiązuje filozofia stania na wielu nogach. Jakkolwiek przedmiotem niniejszego artykułu były rolnictwo i usługi turystyczne, należy mieć na względzie w dalszych analizach przemysł i usługi finansowo-bankowe.

\section{Literatura}

African Development Bank. (2016). Feed Africa. Strategy for Agricultural Transformation in Africa. Abidjan: African Development Bank

Alejziak, W. (2000). Turystyka w obliczu wyzwań XXI wieku. Kraków: Wydawnictwo ALBIS.

Bank Światowy (2017). Pobrane 15 kwietnia 2017 r. z: http://data.worldbank.org.

Digest of International Travel and Tourism Statistics $(2011,2016)$. Port Louis: Ministry of Finance and Economic Development, Mauritius.

FAO Statistical Pocketbook. (2015). Rome: Food and Agriculture Organization of the United Nations.

Garbicz, M. (2012). Problemy rozwoju i zacofania ekonomicznego. Dlaczego jedne kraje są biedne, podczas gdy inne są bogate? Warszawa: Oficyna a Wolters Kluwer business.

Giezgała, J. (1969, 1977). Turystyka w gospodarce narodowej. Warszawa: Polskie Wydawnictwo Ekonomiczne.

Godwin, P. (2001). Rezerwat bez granic. National Geographic, 11.

Human Development Report (2016). UNDP.

Informator Ekonomiczny MSZ (2017). Pobrane 15 września 2017 r. z: http://www.informatorekonomiczny.msz. gov.pl/pl/afryka/mauriutius/.

Jasiński, M. (2006). Aspekty monokulturowe gospodarki turystycznej. Zeszyty Naukowe Kolegium Gospodarki Światowej, 20, 92-102.

Jasiński, M. (2008). Zrównoważony rozwój w monokulturowych gospodarkach turystycznych. W: S. Wodejko (red.) Zrównoważony rozwój turystyki. Warszawa: Szkoła Główna Handlowa w Warszawie.

Jasiński, M. (2017). Modele rozwoju gospodarczego a poziom rozwoju społecznego i zamożności w małych państwach wyspiarskich na świecie. Studia i Prace WNEIZ US, 49/2, 317-333.

Jędrusik, M. (2005). Wyspy tropikalne. W poszukiwaniu dobrobytu. Warszawa: Wydawnictwo Uniwersytetu Warszawskiego.

Kachniewska, M., Niezgoda, A., Pawlicz, A. (2012). Globalizacja i internacjonalizacja działalności turystycznej. W: M. Kachniewska, E. Nawrocka, A. Niezgoda, A. Pawlicz (red.) Rynek turystyczny. Ekonomiczne zagadnienia turystyki. Warszawa: Oficyna a Wolters Kluwer business.

Kurek, W. (red.). (2007). Turystyka. Warszawa: Wydawnictwo Naukowe PWN.

Przewodnik Travel Planet (2017). Pobrano 15 września 2017 r. z: http://www.travelplanet.pl/przewodnik/ mauritius/gospodarka.html.

UNCTAD. (2010). In-depth evaluation of UNCTAD's technical cooperation activities dedicated to least developed countries, landlocked developing countries, small island developing states and other structurally weak, vulnerable and small economies.

Włodarczyk, B. (2009). Przestrzeń turystyczna. Istota, koncepcje, determinanty rozwoju. Łódź: Wydawnictwo Uniwersytetu Łódzkiego.

Wodejko, S. (1989). Ruch przyjazdowy z zachodu do wybranych państw socjalistycznych jako wyraz luki na europejskim rynku turystycznym. Warszawa: SGPiS, Monografie i Opracowania, nr 288.

Wodejko, S. (1998). Ekonomiczne zagadnienia turystyki. Warszawa: Wyższa Szkoła Handlu i Prawa. 